\title{
"SO THIS WAS A MARRIAGE!": INTERSECTIONS OF NATURAL IMAGERY AND THE SEMIOTICS OF SPACE IN ZORA NEALE HURSTON'S THEIR EYES WERE WATCHING GOD ${ }^{1}$
}

\author{
InÉs CASAs Maroto \\ University of Santiago de Compostela
}

\begin{abstract}
Zora Neale Hurston's Their Eyes Were Watching God narrates a black woman's flight for liberation from patriarchal control, in search of her own physical and inner space in a society of men who impose their views and exert their power over women. In her journey towards selfknowledge, Janie interacts with different spaces which represent the dominant culture's models of selfhood, which can be effectively related to the use of natural imagery. As Janie becomes more of her 'natural' self and less a victim of patriarchy and the whims of others, the setting of the novel moves closer to the natural world. Through the use of natural imagery and symbolism, Hurston not only represents the African American valuing of the natural and spiritual world, but also portrays the development of an African American woman in search of her own voice.
\end{abstract}

Keywords: Zora Neale Hurston, African American identity, female identity, nature, symbolism, space semiotics.

\footnotetext{
1 The research leading to the publication of this paper was funded by the Spanish Ministry of Economy and Competitiveness (Project FFI 2010-17061).
} 


\title{
"SO THIS WAS A MARRIAGE!": INTERSECCIONES ENTRE IMÁGENES NATURALES Y LA SEMIÓTICA DEL ESPACIO EN SUS OJOS MIRABAN $A$ DIOS, DE ZORA NEALE HURSTON
}

\begin{abstract}
RESUMEN. Sus ojos miraban a Dios, de Zora Neale Hurston, narra la buida de una mujer negra en busca de liberación del control patriarcal y de su propio espacio físico e intelectual en una sociedad de hombres que imponen su visión y ejercen su poder sobre las mujeres. En su camino para conocerse a si misma, Janie interactúa con diferentes espacios que representan los modelos de individualidad de la cultura dominante, que se pueden relacionar de forma eficaz con el uso de imágenes naturales. A medida que Janie se acerca a su propia identidad natural y se aleja del modelo victimizante del patriarcado y del sometimiento a los caprichos de otros, el marco de la novela se desplaza hacia el mundo de la naturaleza. Por medio del uso de imágenes y símbolos naturales, Hurston no sólo representa el valor que la cultura afroamericana le da al mundo natural $y$ espiritual, sino también el desarrollo personal de una mujer afroamericana en busca de una voz propia.
\end{abstract}

Palabras clave: Zora Neale Hurston, identidad afroamericana, identidad femenina, naturaleza, simbolismo, semiótica del espacio.

Received 15 March 2013

Revised version accepted 20 June 2013

Zora Neale Hurston's Their Eyes Were Watching God is the story of a black woman in search of her own physical and inner space. The account of her journey toward self-actualization comprises the narrative. In her flight for liberation from patriarchal control, to be an autonomous woman in a society of men who insist on defining her reality in their selfish terms, Janie interacts with different spaces which represent the dominant culture's models of selfhood. The main focus in this essay will be on the complex interrelation between space and the models of selfhood which Janie tries out (as well as her rejection of space as a means of domination) in relation to natural imagery. In presenting a succession of three marriages, the first wholly unsuccessful, the second mostly unsuccessful, and the third successful but for the outrages of fortune, Hurston invites a reading of Janie's predicament in terms of the quest motif (Miller 2004: 77). ${ }^{2}$ Over the

\footnotetext{
2 Their Eyes Were Watching God has often been seen in terms of the quest motif: Janie on two occasions leaves established social positions for a more adventurous life, experiences the underworld of the hurricane, is taken to court after shooting her third husband in self-defence and returns home in Eatonville with the knowledge and the experience that she acquired the hard way.
} 
course of the novel we see Janie moving through different houses, each of them representing some experience of confinement of consciousness, with the exception of the place she shares with Tea Cake in the Everglades. In the novel's frame we meet Janie back in Eatonville, where she lives as an artist figure that can enrich the life of the community around her with stories about her quest for self-discovery and self-definition. Thus the novel establishes a prolific tension between an individual and a communal dimension -as the community benefits from the story of the woman who has been "tuh the horizon and back" (Hurston 2007: 257)- between the impulse for adventure and the return to the homeplace. ${ }^{3}$

The tension between these two impulses is effectively articulated through the symbolic dimension of the Horizon, one of Janie's favourite metaphors, which stands for exploring life to the fullest. Janie's desire for self-knowledge gained through experience is expressed in opening and recurrent references to the Horizon. Moreover, Janie wants to express herself in a way that feels natural and organic; to do so, she must resist others' attempts to impose their own visions for her life. The reliance on the strength of natural imagery to sustain significance is a distinct characteristic of black American women writers; as Sivils has put it, in southern literature, trees often "function as connecting points between human experience and the natural world, as anchors in time, place, and human spiritual consciousness" and "serve as semiotic platforms, dynamic frameworks upon which writers place a seemingly endless variation of symbols or meanings" (2006: 91). Thus, Hurston's use of trees and other natural images throughout the novel help to shore up her overall depiction of Janie as "a woman in touch with nature on an elemental, organic level, and for whom the desire for the sexual and other experiences that will shape her identity is as natural as the trees, flowers, and even the hurricane she experiences in the Everglades" (King 2008: 60), where she undergoes the most intense aspect of her transformation.

The most crucial episode in Janie's search for selfhood is when, at the age of sixteen, she awakens to passion in the 'pear tree scene'. It occurs during the spring, and the narrator uses explicit sexual imagery to express her discovery of sexual desire:

She was stretched on her back beneath the pear tree soaking in the alto chant of the visiting bees, the gold of the sun and the panting breath of the breeze when the inaudible voice of it all came to her. She saw a dust-bearing bee sink into the sanctum

\footnotetext{
3 I will be using the abbreviated form TEWWG to quote from the novel hereafter. All quotes have been taken from the Virago edition referenced in the final bibliographical list.
} 
of a bloom; the thousand sister-calyxes arch to meet the love embrace and the ecstatic shiver of the tree from root to tiniest branch creaming in every blossom and frothing with delight. So this was a marriage! She had been summoned to behold a revelation. Then Janie felt a pain remorseless sweet that left her limp and languid.

After a while she got up from where she was and went over the little garden field entire. She was seeking confirmation of the voice and vision, and everywhere she found and acknowledged answers. A personal answer for all other creations except herself. She felt an answer seeking her, but where? When? How? She found herself at the kitchen door and stumbled inside. In the air of the room were flies tumbling and singing, marrying and giving in marriage. When she reached the narrow hallway she was reminded that her grandmother was home with a sick headache. She was lying across the bed asleep so Janie tipped on out of the front door. Oh to be a pear tree any tree in bloom! With kissing bees singing of the beginning of the world! She was sixteen. She had glossy leaves and bursting buds and she wanted to struggle with life but it seemed to elude her. (TEWWG: 14-15).

Janie's awakening to romance and sexual desire constitutes a powerful antithesis to her grandmother Nanny's metaphors of the black woman as the mule of the world and the spit-cup of men, with all their suggestion of dehumanization and sexual exploitation. Replete with the promise of fecundity, the pear tree argues against the tyranny of control that Nanny unwisely, perhaps unwittingly, chooses. Janie's dream is of a sexuality without hierarchies or domination, a relationship of reciprocity and mutual consent in which the "sistercalyxes" gladly "meet the love embrace" of the "dust-bearing bee". Moreover, as González-Groba has put it, her dream is "not just one of sexual fulfilment, but also of creativity and self-expression, as suggested by the idea of pollination" (2008: 118). From this moment of epiphany on, Janie's existence will become a continuous struggle to bring her own experience into harmony with her initial vision of the pear tree. As the novel progresses, this connection becomes "fleshed out" as she experiences marriage with Logan Killicks, Jody Starks, and Tea Cake (Dilbeck 2008: 103); the men in her life will be repeatedly described in terms of how they compare to this vision.

After her epiphany, Janie becomes acutely aware of the confinement and limitation of her life with Nanny:

Where were the singing bees for her? Nothing on the place nor in her grandma's house answered her. She searched as much of the world as she could from the top of the front steps and then went on down to the front gate and leaned over to gaze up and down the road. Looking, waiting, breathing short with impatience. Waiting for the world to be made. (TEWWG: 15-16). 
"SO THIS WAS A MARRIAGE!": INTERSECTIONS OF NATURAL IMAGERY AND THE SEMIOTICS...

Back outside she wonders where the associations of the pear tree are in her life, but she is unable to find them in her grandma's house. The final lines in the passage juxtapose that small part of the world which Janie can see "from the top of the front steps" with the vast possibilities suggested by the open road that Janie "gaze[s] up and down", the open road of the life whose many difficult bends and intersections she will have to overcome. This is the first of several instances in the novel in which we see Janie breaking free from the confinement of restricted spaces and onto the open road, in search of both outer and inner experience. Her life, in fact, is going to constitute a succession of confinements which she will have to resist, break out of, or in some way accommodate to until she finds a space in which she can be queen.

At the sight of "Johnny Taylor lacerating her Janie with a kiss" (TEWWG: 16) over the front gate, Nanny realizes that neither her house nor her fence can protect her granddaughter. Now that Janie has entered the first blossom of womanhood, Nanny wants to prevent her from becoming a space for shiftless and unscrupulous men to foul up. More concerned about Janie's survival than her self-possession, Nanny insists that Janie should marry against her will: she sees in marriage the potential for Janie to have both the protection and the respectability that neither she nor her disgraced daughter had. Her candidate is Logan Killicks, who owns sixty acres of land. Nanny's mentality is the product of her experience as a slave woman, when she had no house of her own and was thus prevented from achieving what the dominant culture defines as selfhood. As a slave, Nanny owned neither her cabin nor her body, and her white master could break into both at will. Nanny explains her "dreams" as "whut a woman oughta be and to do" (TEWWG: 17). As Fulmer puts it, this includes "translating her ideal of setting an African American woman 'on high' into a narrow and literal application of marrying Janie off" (2007: 54) to a man with the only "organ in town" and "a parlor" (TEWWG: 31). She is convinced that without the "protection" of a male-owned home (TEWWG: 20), her Janie will face a future of physical and spiritual destruction: "And Ah can't die easy thinkin' maybe de menfolks white or black is makin' a spit cup outa you" (TEWWG: 27).

Despite the vivid and sympathetic description of Nanny's struggles and her good intentions (she only wishes that Janie could have what she could not achieve), Hurston plants the seed of Janie's later rejection of her grandmother's worldview (Fulmer 2007: 54). In a "biblical allusion to a promised land that Nanny has hoped but failed to provide" (Weathers 2005: 205), she tells Janie that she had intended to "throw up a highway through de wilderness" (TEWWG: 15). However, in the trajectory of Hurston's plot, the implication is that setting up such narrow criteria to what a woman "ought" to be and do leads to 
suffering. Nanny's conception of the black woman as the mule of the world and the spit cup of men leaves Janie no room for independent thought or action, and militates against her dream of ecstatic union as symbolized by the blossoming pear tree. In fact, during the conversation on Janie's upcoming marriage, the narrator states that "the vision of Logan Killicks was desecrating the pear tree, but Janie didn't know how to tell Nanny that" (TEWWG: 18-19). The vision of Logan Killicks imposed by Nanny is incompatible with Janie's idealized vision of marriage as a pear tree. Understanding that life with Logan represented neither the Horizon (possibility) not the sexual expression associated with life, spring and the pear tree in bloom, Janie tried to make the best of an unhappy situation. Moreover, to Janie's vision of herself as a blossoming pear tree, Nanny opposes one which identifies Janie and herself with a lifeless variant of the vegetal image: "us colored folks is branches without roots and that makes things come round in queer ways" (TEWWG: 21). Janie ultimately rejects Nanny's ideas, and as a result, just before she throws off the supposedly privileged life gained from Joe Starks, which she had been trained by Nanny to want, she makes a startling statement: "Nanny had taken the biggest thing God ever made, the horizon [...] and pinched it in to such a little bit of a thing that she could tie it about her granddaughter's neck tight enough to choke her. She hated the old woman who had twisted her so in the name of love" (TEWWG: 120). Nanny becomes in Janie's eyes the great transgressor against her granddaughter's space.

Logan Killicks gives Janie the economic security and the marital legitimacy at the heart of Nanny's obsession, but no joy, no understanding, no imagination or creativity, and, most significantly, no means of connection with the world outside his fenced-in property. In Killicks's secluded farm, Janie, rather than protected, feels intolerably isolated: "It was a lonesome place like a stump in the middle of the woods where nobody had ever been" (TEWWG: 29). In the oppressive and lonely rural space through which he defines himself (and tries to define his young wife) Janie will never be able to explore the questions about life posed during her sensuous encounter with the pear tree. Killicks acts like a slave master with his insults and threats of violence when Janie refuses to obey him, so rather than a means of protection, the walls of his house and the fence around his sixty acres are barriers to the sense of self that Janie discovered under Nanny's pear tree, a self connected sexually and spiritually with the world around her.

After Nanny's death, Janie prepares for a new phase in her quest, far from the restricted notion of selfhood imposed by her grandmother and represented by Killicks's fenced property. Jody Starks appears in Janie's life as an ambitious, glamorous, virile stranger: "It was a citified, stylish dressed man with his hat set 
at an angle that didn't belong in these parts [...] He whistled, mopped his face and walked like he knew where he was going [...] He didn't look her way nor in other way except straight ahead" (TEWWG: 37). Trees act as "launching points for stages of Janie's life" (Sivils 2006: 95), and it is no accident that she is sitting under an oak when Joe Starks, her soon to be second husband, first walks into her life; Janie and Joe first talk under a tree and later meet daily "in the scrub oaks across the road" ( $T E W W G$ : 39). Though Jody does not represent the pear tree in bloom for Janie any more than Logan does, he represents the Horizon and possibility, an escape from the secluded space she occupies with Killicks:

Every day after that they managed to meet in the scrub oaks across the road and talk about when he would be a big ruler of things with her reaping the benefits. Janie pulled back a long time because he did not represent sun-up and pollen and blooming trees, but he spoke for far horizon. He spoke for change and chance. (TEWWG: 39).

The journey away from Killicks's farm is her first voluntary movement in space, unlike her two previous moves: from the white folks' yard to Nanny's house and from there to Killicks's place. On the morning when she discards the apron that marks her as Killicks's slaving wife, she experiences a feeling of "sudden newness and change" with echoes of the pear tree image:

The morning road air was like a new dress. That made her feel the apron tied around her waist. She untied it and flung it on a low bush beside the road and walked on, picking flowers and making a bouquet. After that she came to where Joe Starks was waiting for her with a hired rig. He was very solemn and helped her to the seat beside him. With him on it, it sat like some high, ruling chair. From now on until death she was going to have flower dust and springtime sprinkled over everything. A bee for her bloom. (TEWWG: 43-44).

If Jody Starks is ever the "bee for her bloom", it is only in the initial stages of the marriage. Janie's initial happiness with Jody recedes when she understands that his plans for her preclude her from expressing herself naturally in the world. From the very beginning of his courtship he never hides his self-centeredness and his hunger for power. He confines Janie too, by limiting her life to the inside of his store and his white house, which resembles that of a slave master (West 2005: 99). He wanted Janie to sit on the pedestal -the black equivalent of the southern lady, beautiful, pure and submissive- without the least concern for her individual wants or needs. She must speak only when spoken to, dress as modestly as he indicates, and stay inside his premises as he dictates; as he states, "she's uh woman and her place is in de home" (TEWWG: 59). Jody never allows Janie any space of her own: she has to live in his space, within the sound of his own voice. He allows Janie to 
express only his views, not herself, as he attempts to colonize her psychological space with his thoughts: "Somebody got to think for women and chillum and chickens and cows" (TEWWG: 100). Forcing her to work in the store gives him the opportunity to humiliate her in public. Thus imprisoned, Janie is wholly excluded from the organic, natural world in which she had her vision of sexual and spiritual power; the marriage thus stifled Janie's natural way of being in the world. Her existence with Jody becomes as lifeless as the virgin trees he cut down to build his house and store, and Janie's response to her silencing is, appropriately, expressed through tree imagery: "It must have been the way Joe spoke out without giving her a chance to say anything one way or another that took the bloom off things" (TEWWG: 60). Both Killicks and Starks desecrate Janie's pear tree vision not only because they fail to arouse or sustain her desire, but also because they try to prevent her from expressing herself, in a novel which undoubtedly establishes a connection between sexual desire and the female voice.

Janie finds her high place on the pedestal dreamed by Nanny too suffocating, and she begins to resist the domination that it represents. In terms of her psychological growth, Janie takes a giant step forward in the well-known scene when she discovers duality and self-division, conveyed in terms of movements in space: "The spirit of the marriage left the bedroom and took to living in the parlor. It was there to shake hands whenever company came to visit, but it never went back inside the bedroom again" (TEWWG: 101). The spirit of the marriage is displaced from the private space of the bedroom to the public domestic space of the parlor, and is replaced with an image of virginity. This contrasts heavily with the conjugal bond as symbolized by the open petal pollinated by the bee: "The bed was no longer a daisy-field for her and Joe to play in" (TEWWG: 101). Spatial metaphors occur later in the same chapter, conveying Janie's reflections after Jody slaps her:

She wasn't petal-open anymore with him. She was twenty-four and seven years married when she knew. She found that out one day when he slapped her face in the kitchen ... Janie stood where he left her for unmeasured time and thought. She stood there until something fell off the shelf inside her. Then she went inside there to see what it was. It was her image of Jody tumbled down and shattered. But looking at it she saw that it never was the flesh and blood figure of her dreams. Just something she had grabbed up to drape her dreams over. In a way she turned her back upon the image where it lay and looked further. She had no more blossomy openings dusting pollen over her man, neither any glistening young fruit where the petals used to be. She found that she had a host of thoughts she had never expressed to him, and numerous emotions she had never let Jody know about. Things packed up and put away in parts of her heart where he could never find them. She was saving up feelings 
"SO THIS WAS A MARRIAGE!": INTERSECTIONS OF NATURAL IMAGERY AND THE SEMIOTICS...

for some man she had never seen. She had an inside and an outside now and suddenly she knew how not to mix them. (TEWWG: 96-97).

After this, Janie and Jody are destined to move in opposite directions, and she begins to find her voice. Her newly acquired double consciousness gives Janie the power to transcend the limitations of space, as we see on the day when "she sat and watched the shadow of herself going about tending store and prostrating itself before Jody, while all the time she herself sat under a shady tree with the wind blowing through her hair and her clothes" (TEWWG: 109). The passage emphasizes the persistent conflict between domestic interiors, where Janie is oppressed and denied a voice (Nanny's, Killicks's and Starks's houses), and the open spaces connected to her dreams of ideal union and sexual fulfilment.

The fact that the conflict between Janie and Jody culminates in an act of speech underlines the strategic importance of language for survival in the novel: such self-expression has been "the project of the male cultural subject, and men have effectively usurped it as their exclusive prerogative through the very gendering of the roles of speaking and listening" (Johnson 1998: 48). When Janie asserts her own voice, she reappropriates her self and her world; Jody dies of this shame inflicted on him by Janie's words, which expose his lack of sexual power. This reveals how, rather than the bourgeois security and wealth represented by Jody Starks, Janie needs freedom to explore herself and the world.

Although Jody Starks constituted a considerable improvement for Janie with respect to the isolated rural world of Logan Killicks, it is not until the beginning of her relationship with Tea Cake that she is allowed to explore new physical and psychological spaces. Jody initially spoke to Janie "for far horizon" (TEWWG: 39), but he soon subjected her to confinement. The upward movement involved in placing Janie on the pedestal "alienated her from her cultural roots and delayed her need to answer the call of adventure" (González-Groba 2008: 128). She feels more in touch with her authentic self than ever before during the downward movement in 'the muck', in the agricultural community of the Everglades. Tea Cake, the man who embodies her dreams more fully than any other, makes it possible for Janie to abandon the vertical space of the two-storey house at the centre of Eatonville in favour of truly horizontal space, as the horizon is the world of possibility, of inspiring journeys, of meeting new people and the acquisition of new values, of the rejection of boundaries and limitations placed on the self.

Tea Cake represents the fusion that Janie desires between the creative sexual impulse of the pear tree vision and the immensity of the far horizon, her two 
favourite metaphors, for so long forced from her consciousness by the oppression she has experienced. He is in touch with his natural and organic self, and thus becomes the life partner Janie has been looking for. He follows the land and its cycles as a migrant worker, letting nature and its seasons direct him. With Tea Cake's entrance, the pear blossom imagery that signifies her sexual awakening returns, and Janie's relationship with him fulfils the promise of real marriage Janie had witnessed in her adolescence, in a process of "rewriting black female sexuality" (Harris 1996: 28): ${ }^{4}$

\begin{abstract}
He looked like the love thoughts of women. He could be a bee to a blossom -a pear tree blossom in the spring. He seemed to be crushing scent out of the world with his footsteps. Crushing aromatic herbs with every step he took. Spices hung about him. He was a glance from God. (TEWWG: 151).
\end{abstract}

The house that Janie shares with Tea Cake in the Everglades is considerably different from the house in which Jody Starks imprisons Janie: it is a modest onestorey building which becomes central to the community, but is on the same physical and social level as those around it. Both Tea Cake and Janie participate in the communal activities. Tea Cake's masculine identity is not threatened by Janie's move into the public space of traditional male rituals like hunting or fishing, or the porch gatherings. He liberates Janie from her previous confined social position, and becomes the "bee" to her "blossom" in more than just one sense. Her blossoming is not just the discovery of her desire for life and connection, but ultimately her fruitful participation in the oral tradition of black culture.

Janie has crossed lines of class and colour to marry Tea Cake -as he is a "black nigger" (TEWWG: 200) and she is a mulatto girl- and in her movement has found space to breathe in a way of life which resisted hierarchical demarcations: he shows her the Horizon. As González-Groba has put it, "the physical and social descent of Janie to the farming area of 'the muck' is ultimately an ascent to higher and more authentic layers of being" (2008: 131). Janie is situated in "the least oppressive social structure afforded by the world of the narrative" (Gaál-Szabó 2001: 89). Down on the muck, an area "in de Everglades round Clewiston and Belle Glade where dey raise all dat cane and string-beans and tomatuhs" (TEWWG: 27), Janie's horizons are expanded by the love and respect she shares with Tea Cake. When Tea Cake asks Janie to work in the fields with him and all the others, he invites her to do something she in fact enjoys, and in no way coerces her to work without a sense of community, as Killicks and Starks did. Both Janie and Tea Cake find happiness picking string

\footnotetext{
4 Moveover, his real surname, Woods, evokes his connection to the natural world. Not only is he Janie's pear tree, but her whole wood of trees.
} 
beans on the muck; in such an environment, Janie finds a "new" landscape, an ecological and social "tropical sublime" (Lowe 2011: 91) that, "rather than iterating and enforcing inequalities of power, creates spaces of opportunity and redefinition" (Hicks 2009: 79). As Mesa-El Ashmawi highlights, Hurston treats the muck as "an ideal, pastoral place where Tea Cake and Janie can wander through the fields, singing, flirting, and, in general, being in love" (2009: 204).

When recounting her experiences to Pheoby, Janie shows no regret for the life she has lived, and proves that the love she experienced with Tea Cake has given her strength and integrity. The tragic death of Tea Cake has left her with the spiritual excitement of having fulfilled at least part of her dream of opening her blossoms to a receptive bee. The death of Tea Cake has put an end to Janie's wanderings in physical space, although not in time or spirit, and she has come to understand the meaning of the horizon:

'Now, dat's how everything wuz, Pheoby, jus' lak Ah told yuh. So Ah'm back home again and Ah'm satisfied tuh be heah. Ah done been tuh de horizon and back and now Ah kin set heah in mah house and live by comparisons. Dis house ain't so absent of things lak it used tuh be befo' Tea Cake come along. It's full uh thoughts, 'specially dat bedroom'. (TEWWG: 256-257).

This is the first time she refers to her house as "home", a space which is no longer oppressive because it is hers and she has been liberated. Its walls are no longer dead and silent, but alive with her experiences of the people and the world without:

The day of the gun, and the bloody body, and the courthouse came and commenced to sing a sobbing sigh out of every corner in the room; out of each and every chair and thing. Commenced to sing, commenced to sob and sigh, singing and sobbing. Then Tea Cake came prancing around her where she was and the song of the sigh flew out of the window and lit in the top of the pine trees. Tea Cake, with the sun for a shawl. Of course he wasn't dead. He could never be dead until she herself had finished feeling and thinking. The kiss of his memory made pictures of love and light against the wall. Here was peace. She pulled in her horizon like a great fish-net. Pulled it from around the waist of the world and draped it over her shoulder. So much of life in its meshes! She called in her soul to come and see. (TEWWG: 258-259).

Though she is in an apparent situation of stasis, Janie's imagination and desire are most active: she has not finished "feeling and thinking", and continues to feel the "kiss of [Tea Cake's] memory". Not defeated by the tragedy of her life, Janie actually transforms it as "the creative artist, endowed with patterns of metaphorical thought which allow her to move freely between the past and the present, the inside and the outside, the dream and the reality" (González-Groba 2008: 132). Her 
imagination transforms the horizon from the object of longing and of genuine exploration into a metaphorical fishnet which she can pull in at will. Her imaginative power retains the horizon in a process that highlights the empoverment of women articulated in the novel's opening: "women forget all those things they don't want to remember, and remember everything they don't want to forget" (TEWWG: 1). Janie seems to be open to the possibilities of the future, as when she pulls in her horizon she finds "so much of life in its meshes". Janie is surrounded with imagery that evokes light and brightness. Natural symbols like the pine tree point toward the universe, and although she is enclosed in the protective warmth of her home, we understand that "within its walls is a place that shines with her own awakening and is brightened by the poetry of her spirit" (Holloway 1987: 73).

The use of natural imagery develops throughout the novel as Janie evolves and attains self-empowerment and voice; she finds her developing maturity symbolically imaged in the blossoming of a pear tree. Though her first two marriages end in failure, she learns something valuable about herself from each of them so that by the time she meets the love of her life she becomes able to express her natural, organic self with confidence. The symbolic importance of the pear tree, which resonates throughout the novel, contrasts with middle-aged Janie's use of the tree image while recounting her story to Pheoby: "Janie saw her life like a great tree in leaf with the things suffered, things enjoyed, things done and undone. Dawn and doom was in the branches" (TEWWG: 11). At this point Janie sees her life "like a great tree in leaf", not in bloom as at sixteen, but representing both positive and negative aspects of her experience. The metaphor symbolizes "a life full of the comic and the tragic, a life full of learning experiences" (King 2008: 59), and serves as a fulfilment of the adolescent wish expressed in the pear tree image. The tree, in this context, is not a symbol of marriage but a balance of opposites, of "things done and undone", which appropriately reflects her newly-developed patterns of metaphorical thought.

Natural imagery becomes a means to convey the idea that Janie has become the artist in the community, as the garden seeds from Tea Cake that she kept and means to plant "for remembrance" (TEWWG: 274) promise a future of growth -a world in which black women are not the mules of the world and are allowed the space they need to speak and to be themselves-. ${ }^{5}$ By means of Tea Cake's seeds, a notion of marriage as a liberating contract between two equal individuals

\footnotetext{
5 Hurston's reliability on oral forms -including folktales, sermons, songs, proverbs and so on- is in keeping with the organic nature of the novel. Their Eyes Were Watching God proceeds from Janie's telling of her own story to Pheoby, and the narrative contains numerous other examples of speechmaking and storytelling which often incorporate elements of the oral tradition.
} 
"SO THIS WAS A MARRIAGE!": INTERSECTIONS OF NATURAL IMAGERY AND THE SEMIOTICS...

is defended at the end of the novel (Frías 1998: 92), and a link is established between the community and nature, as Hurston writes of nature as a "physical or spiritual force, one that can or cannot be affected by human forces" (Holloway 1987: 54). For Hurston it is critical for characters to acknowledge the potential of nature, to recognize its role in their communities and to accord it due respect: as Janie becomes more of her 'natural' self and less a victim of the whims of others, the setting of the novel moves closer to the natural world. Janie undertakes "a pastoral retreat into the wilds of her inner nature (which actually corresponds to her actual journey) only to return and reform the self, which has been made less authentic by a male-dominated culture" (Rieger 2009: 92). Through her use of natural imagery, therefore, Hurston represents the African American valuing of the natural and spiritual world, and portrays the development of an African American woman in search of her own voice.

\section{REFERENCES}

Dilbeck, Keiko. 2008. "Symbolic Representation of Identity in Hurston's Their Eyes Were Watching God". The Explicator 66 (2): 102-105.

Frías, María. 1998. El Discurso del Matrimonio en la Obra de Zora Neale Hurston: "Marriage doesn't make love". Madrid: Universidad de Alcalá, Servicio de Publicaciones.

Fulmer, Jacqueline. 2007. Folk Women and Indirection in Morrison, Ni Dhuibhne, Hurston, and Lavin. Aldershot, Burlington: Ashgate.

Gaál-Szabó, Péter. 2001. "Zora Neale Hurston's Cultural Space and African American Spatiality". Hungarian Journal of English and American Studies 17 (1): 85-99.

González-Groba, Constante. 2008. On their Own Premises: Southern Women Writers and the Homeplace. Valencia: Publicacions de la Universitat de València.

Harris, Trudier. 1996. The Power of the Porch: The Storyteller's Craft in Zora Neale Hurston, Gloria Naylor, and Randall Kenan. Athens, Georgia: The University of Georgia Press.

Hicks, Scott. 2009. "Rethinking King Cotton: George W. Lee, Zora Neale Hurston, and Global/Local Revisions of the South and the Nation”. The Arizona Quarterly 65 (4): 63-93.

Holloway, Karla F.C. 1987. The Character of the Word: The Text of Zora Neale Hurston. New York: Greenwood.

Hurston, Zora Neale. 2007 (1937). Their Eyes Were Watching God. New York: Virago. 
Johnson, Yvonne. 1998. The Voices of African American Women: The Use of Narrative and Authorial Voice in the Works of Harriet Jacobs, Zora Neale Hurston, and Alice Walker. New York: P. Lang.

King, Lovalerie. 2008. The Cambridge Introduction to Zora Neale Hurston. Cambridge, New York: Cambridge University Press.

Lowe, John W. 2011. "Nineteenth-Century Southern Writers and the Tropical Sublime". Southern Quarterly 48 (3): 90-115.

Mesa-El Ashmawi, Yvonne. 2009. "Janie's Tea Cake: Sinner, Saint, or Merely Mortal?". The Explicator 67 (3): 203-207.

Miller, Shawn E. 2004. "'Some Other Way to Try': From Defiance to Creative Submission in Their Eyes Were Watching God'. Southern Literary Journal 37 (1): 74-96.

Rieger, Christopher. 2009. Clear-cutting Eden: Ecology and the Pastoral in Southern Literature. Tuscaloosa: University of Alabama Press.

Sivils, Matthew Wynn. 2006. "Reading Trees in Southern Literature". Southern Quarterly 44 (1): 88-103.

Weathers, Glenda B. 2005. "Biblical Trees, Biblical Deliverance: Literary Landscapes of Zora Neale Hurston and Toni Morrison". African American Review 39 (2): 201-213.

West, Margaret Genevieve. 2005. Zora Neale Hurston and American Literary Culture. Gainesville: University Press of Florida. 